Japanese Research in Business History 2013 | 30

\title{
The Development of the Furniture Industry in the Producing Area of Fuchū during Japan's Period of High Economic Growth
}

\author{
Feng Zhang \\ Hiroshima University
}

\section{Introduction}

$\mathrm{W}$

ITH REGARD to the research on small and medium-sized enterprises in postwar Japan, the "industrial cluster model" which highlights the merits of clusterization of interrelated, smaller businesses has recently gained ground, replacing the "dual-structure model" which stresses the fragility of smaller businesses in terms of company size (Itami, Matsushima and Kikkawa, 1998; Suzuki, Daitō and Takeda, 2004). Among the protagonists of the "industrial cluster model", Seki Mitsuhiro sets out and names two types of industrial clusters: industrial clusters in metropolitan areas and those in provincial areas (Seki, 1991). Similar kinds of typology can also be found in the postwar research literature on smaller businesses and local industries (Kiyonari, 1972, Chap. III; Itakura and Kimura, 1980, Chap. I Sec. I). In general, despite slight differences in terminology, industrial clusters in metropolitan areas are characterized by make-to-order or small-lot production of a variety of high-grade special goods, and those in provincial areas, by quantity production of low-priced goods. This generalization, however, fails to grasp the dynamic change of industrial location which took place between metropolitan and provincial areas after the War, especially during the period of high economic growth. This study, 
therefore, aims to illustrate the mechanism of the clusterization specific to smaller businesses and revise the prevailing generalization, taking up the furniture-making industry where industrial clusters in provincial areas, while replacing those in metropolitan areas, developed remarkably during the high economic growth period as centers of quantity production supplying middle or high-grade goods.

In postwar Japan, the furniture industry has been not only regarded as an important consumer durable industry but also as a "livingware industry" (Tsūshōsangyō-shō Seikatsusangyō-kyoku, 1976) and an "interior products industry" (Kitazawa, 1979). As Kitazawa Yasuo points out, the production and distribution structure of the furniture industry, particular in the wooden furniture industry of postwar Japan, is rather complicated. (Kitazawa, 1979, Chap. II) While large producers have vertically integrated the production and distribution processes, small and medium-sized enterprises, which constitute most of the industry, have clustered in producing areas and developed their business, relying on such intermediate distributors as wholesalers in each producing area. There are some previous studies on the wooden furniture industry dealing with industrial clusters of smaller enterprises. For instance, an investigation into small and medium-sized manufacturing enterprises conducted by the Investigating Committee on Small and Medium-sized Enterprises (Chūshōkigyō Chōsakai, 1960) and an investigation into local industries conducted by Yamazaki Mitsuru (Yamazaki, 1977, 179-184) take up topics such as technological progress and quantity production. However, the former only deals with the period until the late 1950s and its interests are limited to smaller businesses and their technological backwardness as opposed to large-scale corporations. The latter, on the other hand, focuses on the critical situation of local industries after the 1973 oil crisis. In all, not enough attention has been paid, concerning the furniture industry during the high economic growth period, to the various production activities of producing areas including active marketing. There are other researches. In the above-mentioned investigation into the interior products industry by Kitazawa, however, the focus of the analysis is set on the late 1970s and the period after that. In addition, Wanshung Hwang's investigation into local industries mainly deals with the situation during and after the 1980s when the strong yen became a serious problem. (Hwang, 1997) In short, so far as the furniture industry during the high economic growth period is concerned, previous 
studies have generally focused on the topics of mechanization and quantity production, while detailed historical analysis is still lacking in production activities of furniture producing areas.

Against this research background, this study presents a case study of a furniture producing area, Fuchū in Hiroshima Prefecture, where is renowned area for the production of high-grade wedding furniture but has hardly been investigated before. By doing so, this study aims to shed a little light on the development of the furniture industry during the period of high economic growth, highlighting the establishment of a quantity production system to supply high-grade products.

\section{The Development of the Japanese Wooden Furniture Industry and the Industrial Position of the Fuchū Furniture Producing Area}

\section{The Development of the Japanese Wooden Furniture Industry}

According to annual Tables of Industrial Statistics, the real shipment value of the Japanese wooden furniture industry was 210.6 billion yen in $1955 .{ }^{1}$ It rose rapidly and reached its peak of 1.9 trillion yen in 197374 , increasing more than 9 times in less than two decades. This growth rate looks even more salient, considering that the shipment value of the whole manufacturing industry increased 6 times during the same period. Although the cabinetwork industry including furniture-making had been developing in the prewar period as well, the real value of production grew only 1.8 times during the period between 1922 and 1936, for which statistical data are available. ${ }^{2}$ Between 1955 and 1973, the number of establishments belonging to the wooden furniture industry remained almost the same and the number of employees within the industry only doubled. In fact, these increasing rates were lower than the average rates for the whole manufacturing industry. However, in per establishment

1. Kōgyō Tōkeihyō [Tables of Industrial Statistics] of each year. For the calculation of the real shipment value, the Consumption Expenditures Index for the private sector (base year: 1990) is used as the deflator. See, Sōmu-shō Tōkei-kyoku [Statistic Bureau, Ministry of Internal Affairs and Communications], Shinban Nihon Chōkitōkei Sōran [The Comprehensive Long-term Statistics of Japan: the new edition] vol. 1 (Nihon Tōkeikyōkai, 2006): 234. The same applies hereafter.

2. Shōkō-shō Tōkeihyō [Tables of Statistics, Ministry of Commerce and Industry] of each year. Kazushi Ōkawa, Kokuminshotoku [The National Income] (Tōyōkeizai Shinpōsha, 1974): 233. The nominal value of production here is of the whole workforce. 
and per employee terms, the real shipment value of the wooden furniture industry grew 8.6 times and 4.4 times respectively for the same period. These rates are remarkable, given that the average rates for the whole manufacturing industry are 3.8 times and 2.9 times respectively for the same period. It should be noted that the growth rate of the shipment value per establishment is more than double the average rate. In terms of establishment size, the proportion of the number of establishments with thirty or more employees increased 3 times from 3\% to $9 \%$, although $90 \%$ of all establishments in the wooden furniture industry remained to hire fewer than thirty employees throughout the whole period. Regarding establishments with thirty or more employees, the ratios of the number of employees, of the shipment value and of the added value, against the number and figures for all establishments in the wooden furniture industry, were all less than $40 \%$ in 1955 . However, these ratios rose rapidly and reached in 1973 , as high as $55 \%, 65 \%$ and $63 \%$ respectively. Concerning establishments with one hundred or more employees, the ratios of both the shipment value and the added value exceeded $30 \%$ in the same year. As shown, the Japanese wooden furniture industry made a conspicuous development during the period of high economic growth, increasing in both establishment size and productivity.

Regarding this development process of the wooden furniture industry, two characteristics should be pointed out. Firstly, the change of industrial positions occurred among major producing areas. Concerning the shipment value of establishments with four or more employees, establishments in Tokyo and Osaka produced 30\% (the former 19\% and the latter 11\% respectively) of all shipment value in 1950 , when the postwar recovery was still under way. Tokyo and Osaka were far ahead of other producing areas at the time. As provincial producing areas developed during the 1960s, however, the difference between metropolitan and provincial areas was reduced. Although Tokyo and Osaka were still positioned in the first and the third places respectively in 1963, they fell back largely and were positioned in the fifth and the sixth places respectively after Aichi, Hiroshima, Shizuoka and Fukuoka Prefectures in 1973. Among these prefectures, the rise of Hiroshima Prefecture was conspicuous. Regarding Hiroshima Prefecture, the shipment value per establishment was 99 million yen in 1973, 6 times the value of 1963. Compared to the figures of Tokyo (31 million yen, 2 times) and Osaka (55 million yen, 4 times), Hiroshima's 
development was far exceeding. Secondly, regional characteristics became distinct in terms of the kinds of goods produced in each major producing areas. Goods categories of the wooden furniture industry consist mainly of "legged furniture" (desks, tables and chairs for household and office use) and "box-shaped furniture" (other household and office furniture). Between 1967 and 1973, the production ratio of legged furniture fell from $27 \%$ to $22 \%$, whereas the ratio of box-shaped furniture rose significantly from $48 \%$ to $55 \%$. Among major producing areas, Aichi Prefecture increased the proportion of legged furniture production during the period and maintained a balanced makeup of goods items produced. Concerning Hiroshima, Fukuoka and Shizuoka Prefectures, on the other hand, the proportion of box-shaped furniture production was still high in 1973; that is, $73 \%, 73 \%$ and $64 \%$ respectively. Considering that these were the top three prefectures in terms of the shipment value of box-shaped furniture, it can be assumed that specialization in the production of box-shaped furniture contributed to the promotion of their industrial positions.

\section{The Development of the Fuchū Furniture Industry and its Industrial Position}

\section{a. The Development of the Fuchū Furniture Industry}

Not much is known about the prewar history of the Fuchū furniture industry. According to Fuchū-shi Shōkōgyō Hattenshi (The Industrial History of Fuchū City), cabinet-making started as a side job on the earthen floor of a farmhouse during the Hōei era (1752-58). It is said that "in the late Taishō and early Shōwa period the number of furniture makers increased and there were more than a hundred makers around presentday Ukai-chō." (Fuchū Shōkō Kaigisho, 1986, 34) According to The Statistics of Hiroshima Prefecture of 1935, the value of the production of cabinets in Ashina-gun (part of present-day Fuchū and Fukuyama Cities and Jinsekikōgen-chō, Jinseki-gun) was as little as less than 240 thousand yen in 1935 , only $7 \%$ of that of Hiroshima City which produced $70 \%$ of all cabinets made in Hiroshima Prefecture. ${ }^{3}$ Therefore, Fuchū can be regarded as a newly-risen furniture producing area which made a rapid growth in

3. Hiroshima-ken Sōmu-bu Tōkei-ka [Hiroshima Prefecture General Affairs Department Statistics Section], Hiroshimaken Tōkeisho [The Statistics of Hiroshima Prefecture], 1935. Hiroshima-ken Tōkeinenkan [The Statistical Yearbook of Hiroshima Prefecture], 2010. 
the postwar period. ${ }^{4}$

The next question is how the Fuchū Furniture producing area developed during the period of high economic growth. According to inquiries made by the Fuchū Furniture Industry Association, the number of affiliated manufacturers, the number of employees hired by affiliated manufacturers and the shipment value produced by affiliated manufacturers changed as follows. The Association was established in February, 1950, as the only furniture makers' association in Fuchū City with 25 affiliated manufacturers, 300 employees and the contribution of 200 thousand yen. ${ }^{5}$ Its membership was limited to "independent business establishments engaged in the production of wooden furniture," that is, furniture manufacturers. ${ }^{6}$ Although the real shipment value was 900 million yen in 1955 , it amounted to 58.9 billion yen in 1975, increasing 63 times in two decades. This increasing rate was far greater than the average rate (9 times) of the whole Japanese wooden furniture industry for the same period. In 1973, in addition, the number of employees per establishment (52.8), the real shipment value per establishment ( 870 million yen) and the real shipment value per employee ( 17 million yen) were all above the national average values, and the increasing rates of these figures since 1955 were also higher than the average increasing rates.

Table 1 shows the distribution of furniture factories in Fuchū by size of employment. Both the number of factories and the number of employees plummeted between 1962 and 1975, so far as factories with fewer than twenty employees were concerned. On the other hand, those numbers rose rapidly during the same period as to factories with thirty or more employees. It should be noted among other things that the numbers of factories and employees increased around three times and four times respectively in the same period concerning factories with thirty or more

4. Juichirō Narita, who held a prestigious position in the woodworking industry, picked up Fuchū as the "representative" of the "newly emerging producing areas of wood furniture" in postwar Japan. See, "Shōkibo Kagukōjō no Keiei [The Management of Small Furniture Factories]," Kagusangyō [The Furniture Industry], Feb. 1967: 56.

5. Fuchū Kagukōgyō Kyōdōkumiai [the Fuchū Furniture Industry Association], Kumiai no Ayumi [The History of the Accociation], 1970. This is owned by the Fuchū Furniture Industry Association.

6. Fuchū Kagukōgyō Kyōdōkumiai [the Fuchū Furniture Industry Association], Teikan [The Articles of the Association], Oct. 1, 1949. This is owned by the Fuchū Furniture Industry Association. 
Table 1 Distribution of Fuchū Furniture Factories by Size of Employment

\begin{tabular}{|c|c|c|c|c|c|c|c|c|c|}
\hline \multirow{3}{*}{$\begin{array}{c}\begin{array}{c}\text { No. of } \\
\text { employees } \\
\text { per factory }\end{array} \\
\begin{array}{c}\text { Less than } \\
10\end{array}\end{array}$} & \multicolumn{3}{|c|}{1962 (Mar.) } & \multicolumn{3}{|c|}{1970 (Apr.) } & \multicolumn{3}{|c|}{1975} \\
\hline & \multirow{2}{*}{$\begin{array}{c}\begin{array}{c}\text { No. of } \\
\text { factories }\end{array} \\
33\end{array}$} & \multicolumn{2}{|c|}{$\begin{array}{c}\text { No. of } \\
\text { employees (\%) }\end{array}$} & \multirow{2}{*}{$\begin{array}{c}\begin{array}{c}\text { No. of } \\
\text { factories }\end{array} \\
19\end{array}$} & \multicolumn{2}{|c|}{$\begin{array}{c}\text { No. of } \\
\text { employees (\%) }\end{array}$} & \multirow{2}{*}{$\begin{array}{c}\begin{array}{c}\text { No. of } \\
\text { factories }\end{array} \\
8\end{array}$} & \multicolumn{2}{|c|}{$\begin{array}{c}\text { No. of } \\
\text { employees (\%) }\end{array}$} \\
\hline & & 153 & ( 15.6) & & 106 & $(4.7)$ & & 52 & $(1.6)$ \\
\hline $10-19$ & 18 & 255 & (26.0) & 12 & 185 & ( 8.1) & 9 & 131 & ( 4.1) \\
\hline $20-29$ & 7 & 170 & ( 17.4) & 7 & 179 & ( 7.8$)$ & 10 & 230 & ( 7.1) \\
\hline $30-49$ & 9 & 341 & $(34.8)$ & 15 & 569 & (25.0) & 17 & 677 & (21.0) \\
\hline $50-99$ & 1 & 60 & ( 6.1) & 5 & 280 & (12.3) & 12 & 794 & (24.6) \\
\hline $100-199$ & & & & 7 & 959 & $(42.1)$ & 6 & 938 & (29.1) \\
\hline $\begin{array}{c}200 \text { or } \\
\text { more }\end{array}$ & & & & & & & 2 & 400 & (12.4) \\
\hline Total & 68 & 979 & $(100.0)$ & 65 & 2,278 & (100.0) & 65 & 3,222 & (100.0) \\
\hline
\end{tabular}

Sources: "Kagugyōshamaibo [The List of Furniture Companies] (Apr. 1 1962)." This is owned by Fuchū Kagukōgyō Kyōdōkumiai [the Fuchū Furniture Industry Association] under the heading of "Bunshotsuzuri [Documents] of fiscal 1962." Kittaka Keisuke, "Fuchūkagu ni Okeru Kōzōkaizen [The Structural Improvement of Fuchū Furniture," Zenkoku Kagukumiairengōkai [the National Furniture Makers' Association], Kagumansurī [The Monthly Furniture Magazine], Oct. 1970: 50. Fuchū Shōkō Kaigisho [the Fuchū Chamber of Commerce and Industry], Fuchū Shōkō Meikan [The Fuchū Business Directory] for the years 1975 and 1978.

but fewer than a hundred employees. Moreover, although there was no factory hiring a hundred or more employees in 1962, there were seven of them in 1970, which employed $42 \%$ of all employees. It can be concluded from these findings that medium-sized manufacturers with thirty or more employees became the backbone of the Fuchu furniture producing area, as the Fuchū furniture industry developed during the 1960s.

Until the beginning of the 1950s, the Fuchū furniture industry mainly comprised the making of Japanese-style chests and its market did not expand beyond Okayama Prefecture. (Mikami, 1967, 10) According to inquiries made by a trade magazine during the $1970 \mathrm{~s},{ }^{7}$ among 65 companies on which the magazine was able to gather information, 57 of them (a little less than 90\%) were manufacturers of wedding furniture sets. In $1973,42 \%$ of their products were sold in the Kinki region, $20 \%$ in the local Chūgoku region, $10 \%$ in the Kantō region, $9 \%$ in the Tōkai region, $7 \%$ in the Shikoku region, $6 \%$ in the Kyūshū region, $5 \%$ in the Tōhoku and the Hokuriku regions and 1\% in Hokkaidō.

7. "Tokushū, Fuchū Kagu no Subete [Special Feature, All of the Fuchū Furniture]," Kagusangyō [The Furniture Industry], Apr. 1977: 130-133. 


\section{b. The Industrial Position of the Fuchū Furniture Producing Area}

According to annual Tables of Industrial Statistics, the value of furniture and other equipment produced in Fuchū City in 1960 was a little less than 800 million yen, which put Fuchū City in the thirty fourth place among producing areas in the whole country. In the same year, Osaka, the top producing area, yielded almost twenty times as much production value as Fuchū. Since then, however, Fuchū's production value of rose sharply and amounted to 24.2 billion yen in 1973, increasing thirty one times in a decade or so. During this period, Fuchū achieved the highest growth rate among all producing areas. Consequently, Fuchū became the seventh largest producing area and the gap between Fuchū and Osaka was narrowed, Osaka now yielding a little less than five times as much production value as Fuchū. Along with the growth of the producing area, constituent companies also developed. With regard to reported profits made by domestic furniture manufacturers from September of 1969 to August of $1970,{ }^{8}$ there were 72 companies around the country which yielded profits of 20 million yen or more, the sum of these profits amounting to 4.76 billion yen. To look at the distribution of these 72 companies by prefecture, the top five were as follows. Aichi had 10 companies with the total profits of 900 million yen; Hiroshima, 14 companies, 770 million yen; Osaka, 8 companies, 470 million yen; Fukuoka, 4 companies, 390 million yen; Tokyo, 9 companies, 340 million yen. Among the 14 companies belonging to Hiroshima Prefecture, 10 were located in Fuchū and their total profits of 350 million yen was higher than that of the 9 companies belonging to Tokyo placed in the fifth position.

Next, regional characteristics of high-grade furniture production will be examined based on a trade magazine, the July 1969 issue of The Furniture Industry, which shows retail prices of 134 storage furniture sets manufactured by 53 prominent companies in 9 producing areas in western Japan. ${ }^{9}$ In the case of companies in eastern Japan, incidentally, most of the 142 storage furniture sets listed in the magazine are average and middle-

8. Kagunenkan [The Furniture Yearbook] (Keizaitsūshin, 1971): 16-17.

9. "Hanbaiten no Tameno Shiireannai: Shūnōsetto (Nishinihonnobu) [A Stocking Guidance for Sales Shops: Cabinet Set (for Western Japan)," Kagusangyō [The Furniture Industry], Jul. 1969: 197. The numbers of furniture sets by prefecture (western Japan) were as follows. Osaka 7, Wakayama 1, Tokushima 3, Kagawa 10, Hiroshima 26, Fuchū 41, Tottori 15, Fukuoka 27, Saga 4. The total number (including 9 regions) was 134. 
grade products belonging to the price range between 130 and 250 thousand yen. By contrast, more than $40 \%$ of the 134 storage furniture sets are highgrade products worth more than 250 thousand yen. With regard to the 41 sets presented by companies of Fuchū, 8 of them belong to the price range between 200 and 250 thousand yen, 10 between 250 and 300 thousand yen, 7 between 300 and 350 thousand yen and 16 sets are worth more than 350 thousand yen. It can be detected that, unlike other producing areas in Hiroshima Prefecture or producing areas in Fukuoka Prefecture where middle-grade furniture was the main product, the production of highgrade furniture was thriving in Fuchū. The market structure of the postwar furniture industry was constituted like a pyramid consisting of common goods, average-grade goods, middle-grade goods and high-grade goods at the top. ${ }^{10}$ Considering that the market share of Fuchū wedding furniture against the whole domestic wedding furniture market was estimated to be $10 \%,{ }^{11}$ it can be assumed that wedding furniture produced in Fuchū held an overwhelming share in the high-grade wedding furniture market.

As has been shown, the newly-risen Fuchū furniture producing area grew rapidly into a prominent high-grade wedding furniture producing area during the period of high economic growth, while industrial positions of metropolitan producing areas such as Tokyo and Osaka relatively declined. In this development process, medium-sized manufacturers became the backbone of the Fuchū producing area and its market expanded to the Kansai, Tōkai and Kantō regions.

\section{The Restructuring of the Production System in the Fuchū High- grade Wedding Furniture Producing Area}

In a trade magazine, the June 1963 issue of The Woodworking Industry, the Fuchū furniture industry is characterized as follows. "Although quantity production generally put a slight on quality, Fuchū has sought to overcome that danger. Both quality and quantity are pursued. Fuchū aims to produce top-quality products in large quantities." ${ }^{, 2}$ In the Sanyō

10. Karino Yuichi,, "Kagukeikaku no Kangaekata to Jissai (2) [Buying Furniture: What to Think, What to Do]," Kagusangyō [The Furniture Industry], May 1965.

11. "Fuchū: Shōhishasaido no Kakaku wo Uchidasu [Fuchū: Set the Price for Consumers]," Kagusangyō [The Furniture Industry], Dec. 1973.

12. "Ōkawa Kagu to Hiroshima Kagu [The Ōkawa Furniture and the Hiroshima Furniture],” Mokkōkai [The Woodworking Industry], Jun. 1963. 
Newspaper dated June 25, 1966, Nobuzō Kurashima, President of Zenkoku Kagukumiairengōkai (the National Furniture Makers' Association), points out as follows. "As each producing area embarked on quantity production, regional traits which existed before have been lost. It is true that standardization of appearances including design and color is going on, which is rather disappointing. However, products of Fuchū in particular keep high quality, have no particular defects and, therefore, are becoming more and more popular." ${ }^{, 13}$ Thus, the characteristic of the Fuchū furnituremaking industry resided in the compatibility of quantity production and the pursuit of high quality, which was the objective Fuchū manufacturers set at a rather early stage of their development. For the establishment of a quantity production system to supply high-grade goods, the restructuring of the existing production system and the progress of the division of labor were crucial, which are the topics of this section and the next.

In the mid-1950s, a product upgrading strategy was adopted as a clear policy by some medium-sized manufacturers and the restructuring of the production system was implemented. A general view on this product upgrading strategy is given before examining the restructuring of the production system. Kuichi Sasaki, President of the Sasaki Mokkō (Sasaki Woodwork Co. established in 1929), looks back on the situation which surrounded the company in the mid-1950s and after and recollects as follows. "Because cabinets made in Fuchū did not have a good reputation back then, I thoroughly thought about how to survive. I went to Kyūshū and Wakayama for studying and aimed for making highquality products." ${ }^{\prime 4}$ The Doi Mokkō (Doi Woodwork Co. established in 1949) and the Marukei Mokkō (Marukei Woodwork Co. established in 1918) were also seeking to upgrade their products and won the Minister of International Trade and Industry Award in the National Excellent Furniture Exhibition in 1961 and 62 consecutively. ${ }^{15}$ In addition, Hiroshi Kozono,

13. "Bingo Tokusanhin Sakkon (8) Fuchūkagu [Special Products in the Western Part of Hiroshima Prefecture (8) Furniture of Fuchū]," Sanyō Shinbun [the Sanyō Newspaper], Jun. 25, 1966.

14. "Toppusanchi no Doryoku to Eikō [Pain and Glory of Top Producing Areas]," Kagumansurī [The Monthly Furniture Magazine], Jun. 1968.

15. Regarding the Doi Woodwork, see "Kōjō Jikoshōkai: Doi Mokkō Kabushikikaisha [Self-introduction of Factory: the Doi Woodwork Co. Ltd.]," Mokuzaikōgyō [The Woodworking Industry], Jul. 1976. Regarding the Marukei Woodwork, see "Yorokobi no Jushōsha: Zenyūten wo Kataru [Delighted Winners Talk about the Zenyu Exhibition]," 
who worked for the Hiroshima Prefectural Woodworking Institution, tried, in his 1959 lecture for the Fuchū producing area, to "upgrade products in order to differentiate them from low-priced furniture mass-produced in other producing areas, because the size and technological features of Fuchū companies seemed suitable for it." ${ }^{\text {16 }}$ It can be detected from these remarks that, from the late 1950s onward, there occurred in the Fuchū producing area an orientation toward high-quality goods production.

Under the circumstances, the restructuring of the production system was attempted at the initiative of some medium-sized companies in order to combine the pursuit of high quality with quantity production. Regarding the development strategies of manufacturers in Fuchū, Nobuyuki Onizuka, President of the Japanese Woodwork Technology Association, who holds a long-term relationship with the Fuchū furniture industry, recollects that around 1961 the Doi Woodwork, the Marukei Woodwork and the Sasaki Woodwork implemented "first, human resource development, and then, planning and development for production management." (Onizuka, 1978, 111-112) This recollection indicates that medium-sized manufacturers were seeking the restructuring of the production system, as well as manpower development. The Doi Woodwork planned, in its 1961 longterm development program, to create a new staff department consisting of the accounting, labor, sale and planning sections in order to grow out of "a woodwork shop of craftsmen." ${ }^{17}$ During the 1950s, this self-recognition as "a woodwork shop of craftsmen" was a commonly shared notion among Fuchū manufacturers. With regard to the Sasaki Woodwork, for instance, apprentices were hired by the day, whereas craftsmen were engaged on piecework at the new workshop established in 1953. (Sasaki, 1979, 5859) Around 1955, in addition, the Marukei Woodwork was referred to as a "semi-farmer, semi-artisan" shop. (Uranishi, 1978, 109) Such craftsmendependent production system was beginning to change in the early 1960s.

According to the organization chart of the Marukei Woodwork, ${ }^{18}$ the

Kagumansurī [The Monthly Furniture Magazine], May 1967.

16. Kozono, Hiroshi, "Kagu no Ishō Kenkyū [A Research on Furniture Design]," Gyōmuhōkoku [Job Report], Hiroshima-kenritsu Mokkōshidōsho [the Hiroshima Prefectural Woodworking Institution], Aug. 1960: 5.

17. “Kōjō Jikoshōkai: Doi Mokkō Kabushikikaisha," op. cit.

18. "Nihon Mokuseihin Gijutsukyōkai Kenshūkai Siryō [Workshop Document, the Japan Woodworking Technology Association].” This is owned by the Fuchū Furniture Industry Association under the heading of "41 Nen Sankōsiryōikken [Reference Papers, 1966]." 
company consisted mainly of the Planning Department (the Planning Section), the Production Department (the First to the Fifth Sections and the Procurement Section), the Sales Department (the Sales Section and the Operations Section), and the General Affairs Department (the Accounting Section and the General Affairs Section). Incidentally, the Doi Woodwork had a similar organizational structure. The characteristic of the organizational structure was, firstly, the establishment of an independent planning department, which was separated from the production department and put in charge of the planning, drawing and trial production of new products. By doing so, the company intended to enhance its development capabilities and control the drawing process of production which had been entrusted to the hands of craftsmen. (Kozono, 1984, 78) Secondly, the manufacturing process (the Production Department) was divided into six sections according to job categories. This measure aimed to secure, together with higher efficiency, the precision, the interchangeability and the quality of parts, which was necessitated by the division of labor resulting from the company's control over the drawing process. In short, the specialized planning department and the expanded manufacturing facilities were the essential technological condition for the establishment of the new production system.

The importance of the planning department was reflected in the characteristic of the design of postwar Fuchū storage furniture. Although ready-made furniture was contrasted with order-made one and considered to be of poor quality in the prewar period, its production grew rapidly in the postwar period, because of the pursuit of design suitable for quantity production. ${ }^{19}$ Thus, in the case of the National Excellent Furniture Exhibition, for instance, "design" and "the possibility of quantity production" were the crucial screening standard. With regard to storage furniture in particular, there was no significant change, unlike the case with chairs, in its design from the functional aspect. In terms of the surface design, however, the appearance of storage furniture changed in various ways on account of material development and progress in woodworking technology. ${ }^{20}$ The history of the design of Fuchū storage furniture can

19. "Kiseikagu no Keikō ni Tsuite [The Trend of Ready-made Furniture]," Mokkōkai [The Woodworking Industry], Jul. 1955: 50.

20. Watanabe, Teruo, "Dezain ni Miru Kagu no Sengoshi [The Postwar History and Design]," Kagumansurī [The Monthly Furniture Magazine], Mar. 1969. 
be divided into two periods. As will be elucidated later, years leading up to the early 1960s were the rising period during which praises such as "the Fuchū era has come" began to be heard. Then came the period of the creation of new design trends during which Fuchū was called "the trendsetter of new storage furniture sets." ${ }^{21}$ The most important feature common to these two periods was the innovation brought about by highgrade techniques concerning the processing of wood veneer. ${ }^{22}$ That is why Fuchū has been referred to, within the furniture industry, as "the producing area of high-grade wood veneer storage furniture" since the mid-1960s. ${ }^{23}$ As the use of so-called "flush structure" (hollow structure) boards spread in the postwar period, especially after the mid-1950s, the use of wood veneer also spread. It became popular as a surface material to make the appearance of furniture look beautiful, since the grain of tropical wood used as plywood did not look attractive. ${ }^{24}$ The quality of facing materials such as wood veneer became crucial for the quality assessment of storage furniture during the 1960s. Furniture with wood veneer of 0.2 to 1 millimeter thickness was evaluated as high-grade product in the market, whereas furniture with grain-printed paper or melamine facing plate was regarded as low-grade one. ${ }^{25}$ Hiroshima City and Ōkawa City, which were Fuchū's rivals, were the exemplary producing areas of relatively lowpriced furniture of average and middle-grade. Melamine facing plate was always the main surface material in Hiroshima. In Ōkawa, by contrast, wood veneer had been used until the end of the 1950s, so that its furniture won the reputation of "Ōkawa tone" in Tokyo. During and after the 1960 s, however, melamine facing plate took the place of wood veneer. ${ }^{26}$

21. "Konshū wo rīdo suru Fuchū [Fuchū Leads This Autumn]," Kagusangyō [The Furniture Industry], Jul. 1969: 174.

22. Sasaki Takeshi (Zenkoku Kagukumiairengōkai Fukukaichō [Vice-President of the National Furniture Makers' Association]), "Tansu to Tana: Sengo 17 Nen [Cabinets and Shelves: 17 Years since the End of the War]," Mokkōkai [The Woodworking Industry], Oct. 1962 .

23. "Hiyakukisu Fuchūgyōkai [The Fuchū Furniture Manufacturers Are Determined to Advance]," Nihon Mokkō Shinbun [the Japan Woodworking Newspaper] (Shūkan Kagu [the Weekly Furniture]) (western Japan version), Sep. 12, 1966.

24. "Demawatteiru Shūnōsetto wo Hadaka ni Suru [Expose the True Qualities of Cabinet Furniture Set in the Market]," Kagusangyō [The Furniture Industry], Mar. 1968: 57.

25. "Konreikagu (2) [Wedding Furniture (2)]," Nihon Keizai Shinbun [the Nikkei Newspaper] (the evening edition), Aug. 20, 1962. "Yoi Kagu no Erabikata [How to Choose Good Furniture]," Nihon Keizai Shinbun (the evening edition), Mar. 30, 1966.

26. Sasaki,Takeshi, op. cit. In the early 1970 s, $80 \%$ of surface materials were melamine 
To examine the surface materials used for storage furniture displayed at the Great Fuchū New Furniture Exhibitions, the proportions of walnut and elm were conspicuously high in the early 1960s. During and after the mid-1960s, however, a variety of surface materials such as rosewood, cherry, ebony and Eurasian teak, let alone walnut, began to be used. ${ }^{27}$ In addition, furniture manufacturers began to be dubbed, for instance, "the Matsuoka of ebony", "the Taiyō of oak", "the Ishioka of rosewood" and so forth, according to the veneer wood they used. ${ }^{28}$ This indicates that these manufacturers were seeking to differentiate and upgrade the design of their furniture by wood veneer. In 1962, the average ratio of the cost of wood veneer against the total production cost of storage furniture was $21 \%$ in the case of 22 manufacturers in Fuchū, in contrast to 6\% in the case of 31 manufacturers in Hiroshima. ${ }^{29}$ The ratio of Fuchū was more than three times as high as that of Hiroshima.

The planning departments of the companies took the initiative in the development of design, which was largely dependent on wood veneer. The Marukei Woodwork, for instance, developed a wood-knobbed cabinet set around 1968, based on the design concept of straight grain of teak. The Planning Office of the company remarks on this incident as follows. "We were particularly enthusiastic about this project. President Kitsutaka checked each drawing. Especially, we took pains in finding the right shape, the necessary strength and the proper making method of the wood knob." Thus, the design of wood veneer was the crucial factor in the product development, and quantity production based on drawing was intended. ${ }^{30}$ At the Doi Woodwork as well, the planning department was the "pivot"

facing plate and vinyl chloride sheet. See "Danketsu to Kyōchō wo Shujiku ni Seihinkōjō de Shinjidai ni Taiō [We Cope with the New Era with Improved Products in the Spirit of Solidarity and Cooperation]," Kagusangyō [The Furniture Industry], Oct. 1975: 132.

27. "Kiseishūnōkagu no Hyōmenkeshōzai Chōsahōkoku [The Report of the Investigation into Facing Materials Used for Ready-made Cabinet Furniture]," Mokuzaikōgyō [The Woodworking Industry], Dec. 1961.

28. "Miryoku no Fuchūshinsaku Shūnōsetto wa Kōshite Tsukurareta [This is how the New, Attractive Fuchū Cabinet Set was Made]," Kagumansurī [The Monthly Furniture Magazine], Aug. 1974.

29. Hiroshima-ken Chūshōkigyō Shidōsho [Hiroshima Prefectural Institute for Small and Medium-sized Businesses], Hiroshima-ken Kaguseizōgyō Gyōshubetu Shindan Hōkokusho [The Report on the State of Hiroshima Furniture Companies by Industry], Feb. 1963.

30. "Tansu ni Inochi wo Kaketa Otoko no Kōzō [The Man Who Put His Heart and Soul into Cabinet]," Sanchi Tokuhō [Special Reports from Producing Areas] (117th issue) (Zenkarenshuppansha, May 1976): 361. 
of product development including the use of wood veneer. The planning department under an experienced chief consisted of a number of staff engaged on trial production, who had learned woodworking at technical or ordinary senior high schools. ${ }^{31}$ As will be shown later regarding the division of labor, however, it should be borne in mind that the development and productization of wood veneer finally depended on the cooperation with wood veneer-related businesses in the same producing area.

According to an inquiry into the Fuchū Furniture Industry Association conducted by the Hiroshima Bureau of International Trade and Industry in 1971, 29 out of 33 affiliated companies were employing planning or design staff. ${ }^{32}$ Among these 29 companies, 15 were those with 50 or more employees, and the average number of planning or design staff hired by these 15 companies was 2.7. The average number of planning and design stuff employed by 10 affiliated companies with 20 or more but fewer than 50 employees was 1.5. In the case of 4 affiliated companies with 9 or more but fewer than 20 employees, the figure was 1.25 . It can be said from these findings that the deployment of planning and design staff was a management strategy adopted not only by medium-sized companies but by small businesses.

With regard to manufacturing equipment, Table 2 shows the timing of Fuchū furniture manufacturers' investment in machinery. According to the 1967 inquiry, out of 705 machines possessed by 25 companies under investigation, 678 machines, more than $90 \%$, had been introduced in the previous ten years. In the case of the 1980 inquiry, out of 2,755 machines possessed by 57 companies, 1,675 machines, a little more than $60 \%$, had been introduced in the previous six years. Although the number of machines per company was 28 in 1967, it increased rapidly and amounted to 48 in 1980. According to Juichirō Narita's estimation regarding the whole domestic storage furniture industry, the number of machines per company was 16 to 17 in the case of companies with 2 to 10 employees, 34 to 36 in the case of companies with 30 to 60 employees, 60 to 70 in

31. Rōdōsha Meibo (1) [The List of Employees (1)] owned by the Doi Woodwork. "Miryoku no Fuchūshinsaku Shūnōsetto wa Kōshite Tsukurareta," op. cit., 159.

32. Hiroshima Tsūshōsangyō-kyoku [Hiroshima Bureau of International Trade and Industry], Moderusanchi Chōsahōkokusho [The Report of the Investigation into Model Producing Areas], 1971: 10. This is owned by the Fuchū Furniture Industry Association under the heading of "Sankashiryōikken [Participation Documents]." 
Table 2 The Timing of Fuchū Furniture Manufacturers' Machinery Investment by Size of Employment

\begin{tabular}{|c|c|c|c|c|c|c|c|c|}
\hline \multirow{2}{*}{\multicolumn{2}{|c|}{$\begin{array}{c}\text { No. of employees } \\
\text { per company }\end{array}$}} & \multicolumn{5}{|c|}{ Timing of Machinery Investment (\%) } & \multirow{3}{*}{$\begin{array}{c}\begin{array}{c}\text { No. of } \\
\text { companies }\end{array} \\
-\end{array}$} & \multirow{3}{*}{$\begin{array}{c}\begin{array}{c}\text { No. of } \\
\text { machines }\end{array} \\
168\end{array}$} \\
\hline & & \multirow{2}{*}{$\begin{array}{c}\begin{array}{c}\text { Less than } \\
2 \text { years }\end{array} \\
25.6\end{array}$} & \multirow{2}{*}{$\begin{array}{l}2-5 \\
\text { years } \\
56.5\end{array}$} & \multirow{2}{*}{$\begin{array}{c}6-10 \\
\text { years } \\
16.7\end{array}$} & \multirow{2}{*}{$\begin{array}{c}11 \text { years } \\
\text { or more } \\
1.2\end{array}$} & \multirow{2}{*}{$\begin{array}{c}\text { Total } \\
100.0\end{array}$} & & \\
\hline \multirow{6}{*}{$\begin{array}{c}\text { The } \\
1967 \\
\text { Inquiry }\end{array}$} & $1-24$ & & & & & & & \\
\hline & $25-49$ & 27.9 & 46.6 & 21.1 & 4.4 & 100.0 & - & 204 \\
\hline & $50-99$ & 28.8 & 38.4 & 28.8 & 4.0 & 100.0 & - & 198 \\
\hline & $100-$ & 20.0 & 52.5 & 21.5 & 6.0 & 100.0 & - & 135 \\
\hline & Average & 26.1 & 47.8 & 22.3 & 3.8 & 100.0 & - & - \\
\hline & Number & 184 & 337 & 157 & 27 & 705 & 25 & 705 \\
\hline \multirow{7}{*}{$\begin{array}{c}\text { The } \\
1980 \\
\text { Inquiry }\end{array}$} & $1-19$ & 7.7 & 21.2 & 49.3 & 20.8 & 100.0 & 18 & 257 \\
\hline & $20-39$ & 8.8 & 30.0 & 32.4 & 28.8 & 100.0 & 12 & 466 \\
\hline & $40-59$ & 13.4 & 21.8 & 39.7 & 25.1 & 100.0 & 13 & 569 \\
\hline & $60-99$ & 12.7 & 29.1 & 42.3 & 15.9 & 100.0 & 5 & 189 \\
\hline & $100-$ & 14.9 & 27.9 & 43.4 & 13.8 & 100.0 & 9 & 1,274 \\
\hline & Average & 12.7 & 26.5 & 41.3 & 19.5 & 100.0 & - & - \\
\hline & Number & 351 & 729 & 1,138 & 537 & 2,755 & 57 & 2,755 \\
\hline
\end{tabular}

Sources: Hiroshima-ken Chūshōkigyō Shidōsho [Hiroshima Prefectural Institute for Small and Medium-sized Businesses], Hiroshima-ken Mokuseikagu Seizōgyō Sanchi Shindan Hōkokusho [The Report on the State of the Wood Furniture Producing Areas in Hiroshima Prefecture], 1968. Hiroshima-ken [Hiroshima Prefecture], Mokuseikagu Seizōgyō (Fuchū-shi) ni Kakawaru Sanchi Chūshōkigyō Shinkō Bijon [A Vision for the Development of Small and Medium-sized Businesses in the Producing Area: the Wood Furniture Industry in Fuchū City], 1980.

the case of companies with 80 to 150 employees. (Narita, 1971) It can be said from these figures that, in terms of company size, small and mediumsized companies in Fuchū grew rapidly into medium-sized and largescale companies between 1967 and 1980. According to the 1980 inquiry, the number of machines per company with 20 or more employees was 64, and so far as companies with 100 or more employees were concerned, the figure was 142 , five times as many as in 1967. Productivity (revenue per company) also increased. In the case of companies with 10 to 29 employees, revenue per company rose four times between 1962 and 1970. It went up three times in the cases of companies with 30 to 49 employees and of companies with 50 to 99 employees. ${ }^{33}$ Loans from financial institutions were crucial for financing these capital expenditures. A trade magazine reports that, as special loans for companies producing special goods, the Peoples's Finance Corporation lent 30 million yen in 1960 and the Shōkō Chūkin Bank lent 40 million yen in 1961. (Fuchū Kagukōgyō

33. Regarding 1962, the figures are based on Bunshotsuzuri [Documents] of fiscal 1962, owned by the Fuchū Furniture Industry Association. Regarding 1970, the figures are based on 71 Kagusangyōsōran [The 1971 Comprehensive Handbook of the Furniture Industry] (Kagusangyō, 1971). 
Kyōdōkumiai, 1975, 21) Around 1962, in addition, the Gotō Kagu (Gotō Furniture Co.) borrowed 3 million yen from the Hiroshima Mutual Bank, which had had no previous business transaction with the furniture company. ${ }^{34}$ It can be assumed from these facts that, along with the People's Finance Corporation and the Shōkō Chūkin Bank, private financial institutions played an important role in the early 1960s. Then, during and after the mid-1960s, private financial institutions specialized in loans for small businesses gradually added to its importance and influence under the business situation where it was widely held as to the furniture industry that "the average profit margin of $9 \%$ was a sure thing." 35 Regarding short-term loans made to 28 companies in 1967-68, for instance, out of a total of 233.41 million yen, 101.69 million yen, more than $40 \%$, was lent by the Hiroshima Mutual Bank, the Kure Bank and the Ashina Credit Association. The amount of the loans made by these private financial institutions was far greater than the amount of loans made by the Shōkō Chūkin Bank, the Small Business Finance Corporation and the People's Finance Corporation. The total of their loans was only 20.23 million yen. ${ }^{36}$

The types of machines introduced can be specified based on the above-mentioned 1967 inquiry into the 25 companies. (Hiroshimaken Chūshōkigyō Shidōsho, 1968, 80) Although the number of general purpose woodworking machines (such as the circular saws, the circular saw benches and the hand planers) which had been introduced before the mid-1950s was only 20 , the number went up rapidly to 102 in the early 1960s. In addition, the number of machines such as the levelling planers, the double saws, the cold presses, the boring machines, the rooter machines, the sanders and the buffing machines also rose from 54 to 103 between the late 1950s and the early 1960s. It should be noted that the introduction of these machines coincided with the technological change from the traditional mortise and tenon joint method ("hozogumi") with "solid-structure" boards to the newly-introduced dowel joint method

34. "Nebari to Konjō no Funsenki: Gotōkagu no Kunanjidai [The Story of Tenacity and Guts: Hard Times for the Goto Furniture Company]," Sanchi Tokuhō, op. cit., 356.

35. Mikami,Ippei, "Tsugi no Mokuhyō ni Ayumi wo Susumeru [Advancing to the Next Target]," Kagusangyō [The Furniture Industry], Apr. 1969.

36. "Kariire Mōshikomisho [Application Form for Loan] (concerning the subletting of the short-term working capital for the summer of 1968 and that for the winter of 1968)." This is owned by the Fuchū Furniture Industry Association under the heading of "Shōkōchūkinikken [the Shōkō Chūkin Bank] (fiscal 1968)." 
("dabogumi") with "flush-structure" boards. ${ }^{37}$ Certain types of machines, however, were scarcely introduced. For instance, there was only one band saw for logs, which had been introduced before 1956. In addition, there were only 14 hot presses for gluing in total, the per company number being as low as 0.5 . Although the hot presses were generally used to glue wood veneer to ordinary plywood, the machines were used, in the Fuchū producing area, for the purpose of gluing plywood, as was the case with the Doi Woodwork. ${ }^{38}$ Moreover, there were only 19 coaters, 0.8 per company. According to Narita's estimation above-mentioned, per company number of the coaters was 2 in the cases of companies with 2 to 10 employees and of companies with 30 to 60 employees. The number of the coaters Fuchū manufacturers possessed was less than half the average. It can be pointed out from these facts that despite the increasing capital expenditure the introduction of machines used for certain process in production was limited to the below-standard level. As will be elucidated in the next section, it was because of the development in the division of labor within the producing area that furniture manufacturers refrained from introducing certain types of machines.

\section{The Progress of the Division of Labor within the High-grade Wedding Furniture Producing Area of Fuchū}

According to Fuchū Shōkō Meikan (The Fuchū Business Directory),

37. "Demawatteiru Shūnōsetto wo Hadaka ni Suru," op.cit., 57-58. Fuchū Kagukōgyō Kyōdōkumiai [the Fuchū Furniture Industry Association], Hiyaku [The Leap] (1975): 122-123. Kōno,Yoshiyuki, “Mokkōkikai no Shinpo [The Development of Woodworking Machines]," Hiroshima-ken Kagukumiairengōkai [the Hiroshima Prefecture Furniture Makers' Association], Hiroshima-ken no Kagu: 20 Nen no Ayumi [The Furniture of Hiroshima Prefecture: 20 Years of Progress] (1978): 145-149. Maeda, Yasumasa,"Fuchūkagu to Tomoni Ayumu [My Life with the Fuchū Furniture]," Fuchū Kagukōgyō Kyōdōkumiai [the Fuchū Furniture Industry Association], Fuchūkagu: 35 Nen no Ayumi [The Fuchū Furniture: 35 Years of Progress] (1985): 89-90. Incidentally, the mortise and tenon joint method ("hozogumi") is a way to joint two pieces of wood in which the tenon formed on the end of a member is inserted into a square hole cut into the corresponding member. The dowel joint method ("dabogumi") is another way to joint two pieces of wood in which round wooden pins of 50-70 millimeters in length ("dabo") are inserted into circular holes of some 10 millimeters in diameter cut into both of the pieces to be jointed. A "solid-structure" board means either a thick plank or a board framed by lumber ("kamachigumi"). A "flush-structure" board is made by gluing plywood to a wooden frame, so that the inside of the board is hollow.

38. Based on an interview with Tetsuya Sadashige, Kaichō [President] of the Sadashige Tokushu Gōhan [Sadashige Special Plywood Co. Ltd.], conducted on Dec. 29, 2008. 
there were 64 furniture-related companies in Fuchū in 1975, 25 of them being parts makers, 27 of them veneered plywood companies (dealers and makers), 11 of them lumber companies, and 11 of them coaters. Regarding the time of foundation of these 64 companies, 7 were established between 1945 and 1949, 7 during the 1950s, and 40 during and after the1960s. In short, most of them were established after the War, especially during the period of high economic growth. (Fuchū Shōkō Kaigisho, 1975) On the other hand, with regard to the time of foundation of 65 furniture manufacturers operating in 1975,8 of them were established during or before the Meiji period, 13 of them during the Taishō period, 13 of them the prewar Shōwa period, 2 of them during the War, 12 of them between 1945 and 1949, 11 of them during the 1950s, 6 of them during and after the 1960s. (Fuchū Kagukōgyō Kyōdōkumiai, 1975, 45-110) Compared to furniture-related companies, furniture manufacturers as a whole have a relatively longer history. This is a reflection of the fact that the rapid development of furniture manufacturers during the high economic growth period prompted the establishment of furniture-related companies within the Fuchū furniture producing area. In fact, furniture manufacturers implemented outsourcing according to the division of the production process shown in Figure 1.

An inquiry conducted in 1967 as to the state of outsourcing concerning 21 furniture manufacturers, shows that 14 of them, a little less than $70 \%$, were implementing outsourcing. (Hiroshima-ken Chūshōkigyō Shidōsho, $1968,84)$ As for the content of the outsourcing, 9 manufacturers contracted out "coating", 5 manufacturers "gluing", 1 manufacturer "drying" and 5 manufacturers "others". The proportion of "coating" was relatively high. According to a similar inquiry conducted in 1980 concerning 41 furniture manufacturers, 23 manufacturers contracted out "lumbering", 10 manufacturers "drying", 1 manufacturer "wood conversion", 11 manufacturers "machining", 7 manufacturers "gluing", 32 manufacturers "coating" and 31 manufacturers "others". Although mechanization had developed to a considerable extent by 1980, production processes such as "coating", "lumbering" and "others" were still largely dependent on outsourcing. Incidentally, "others" mainly comprised parts making such as the making of drawers. Around 1970, the Sasaki Woodwork had four parts 
Figure 1 The Production and Distribution Structure of the Fuchū Furniture Producing Area in the Postwar Period Wholesale

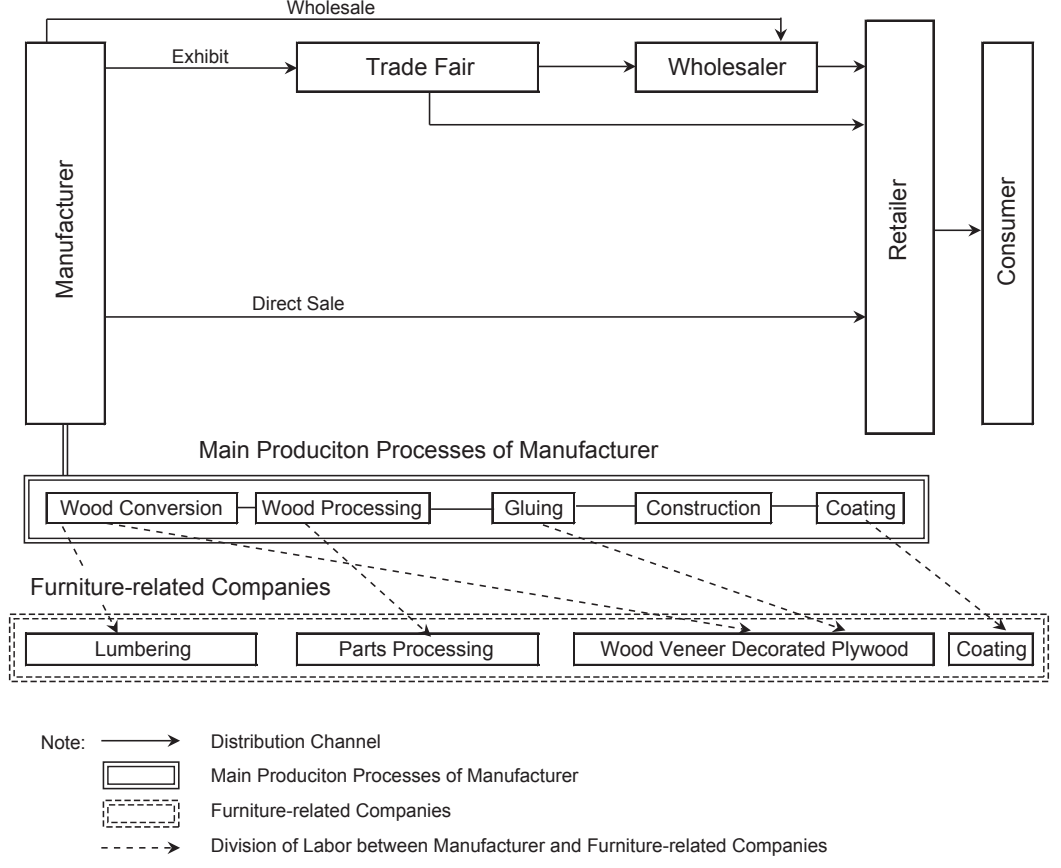

makers as outsourcing contractors. ${ }^{39}$ With regard to "lumbering", the Sasaki Woodwork and others contracted with the Miyahara Ranbā (Miyahara Lumber Co. established in 1961) for the purchase of logs and lumber. Most of the material the Sasaki Woodwork purchased was lumber processed by the Miyahara Lumber's sub-contractors. ${ }^{40}$ Three of the five sub-contractors were in Matsunaga and two of them in Fuchū. With regard to the reason why there were so many cases where "coating" was contracted out, it is held that "facilities, environmental pollution and technical problems with coating" were the factors. (Hiroshima-ken, 1980, 31)

It can be conjectured that the division of labor between furniture manufacturers and veneered plywood companies, whose number was

39. Based on an interview with Kazunori Kawamoto, Shachō [CEO] of the Sasaki Mokkō [Sasaki Woodwork Co. Ltd.], conducted on Dec. 24, 2008.

40. Based on an interview with Susumu Miyahara, Kaichō [President] of the Miyahara Ranbā [Miyahara Lumber Co.], conducted on Mar. 16, 2009. 
largest among furniture-related companies, was formed at an early stage of the industry's development concerning the purchase and the processing of material, although that cannot be corroborated by the above-mentioned inquiries. As shown earlier, there were 27 veneered plywood companies in 1975. Among them, 23 were established in the postwar period: 3 of them in the 1950 s, 15 of them in the 1960s and 5 of them in the early 1970s. In terms of the development in size, the following three companies, which are among the five oldest, stand out: the Karakawa Mokuzaikōgyō (Karakawa Lumber Co. established in 1927), the Sadashige Tokushugōhan (Sadashige Special Plywood Co. established in 1954) and the Nakatō Sangyō (Nakatō Industrial Co. established in 1919). Regarding the number of employees, the Karakawa Lumber was classified as a company with 50 or more but fewer than 100 employees in 1963. By 1975, however, it had developed into a company with 250 employees. Likewise, the Sadashige Special Plywood was a company with 50-99 employees in 1963, but employing 450 employees in 1975. The Nakatō Industrial was a company with 30-49 employees in 1963, but employing 116 employees in 1975. Regarding the value of tangible fixed assets, it rose rapidly from 49.01 million to 111.16 million yen between 1963 and 1966 in the case of the Karakawa Lumber. Concerning the Sadashige Special Plywood and the Nakato Industrial, it also increased markedly from 28.2 million to 55 million yen and from 12.8 million to 39.8 million yen respectively during the same period. ${ }^{41}$

It should be noted that wood veneer for furniture was not produced in Fuchū but purchased from Tokyo and Osaka through veneered plywood companies. There were eight major veneered plywood companies, including the Karakawa Lumber and the Sadashige Special Plywood as leading companies. ${ }^{42}$ Concerning the reason why wood veneer for furniture was not produced in Fuchū, it is said that, while wood veneer used as construction material was standardized, "there were too many factors concerning design and material" in the case of wood veneer for furniture. ${ }^{43}$

41. Regarding the years 1963 and 1966, the figures are based on Hiroshima-ken Fuchūshi [Fuchū City, Hiroshima Prefecture], Jigyōshomeikan [The Factory Directory] (yearly). Regarding 1975, the figures are based on Fuchū Shōkō Kaigisho [the Fuchū Chamber of Commerce and Industry], Fuchū Shōkō Meikan [The Fuchū Business Directory], 1975.

42. Based on an interview with Tetsuya Sadashige, President of the Sadashige Special Plywood, conducted on Feb. 3, 2009.

43. Based on an interview with Tetsuya Sadashige, President of the Sadashige Special Plywood, conducted on Dec. 29, 2008. 
The preceding President of the Karakawa Lumber, who was originally from Fuchū, went to Pusan and founded the company there in 1927, purchasing wood veneer mainly from the Hokusan Co. in Tokyo. After the War, Takuji Karakawa, the second President, resumed the business in Fuchū around 1947. He "not only went to the workshop himself to teach how to glue boards, but frequently visited wood veneer factories in Osaka to check every sheet of wood veneer, picked out only good ones with beautiful grain and brought them back to Fuchū." ${ }^{, 4}$ Thus, he is said to have contributed to the popularization of wood veneer. The Sadashige Special Plywood was the first postwar plywood company in Fuchū founded by Takeshi Sadashige who had completed his one year training at the Nakatō Industrial. It is said that "he paid good money for good veneer and good veneer was gathered at the Sadashige." In 1959 the President of the National Furniture Association Award was won by the Miyazaki Kagukōgyō (Miyazaki Furniture Co. established in 1916), the first Fuchū company to win the Award. Around 1965 wood veneer furniture became a hit product of the Takashimaya Department Store. On both occasions, the walnut veneer used was a product of the cooperation with the Sadashige Special Plywood. ${ }^{45}$ The Sadashige Special Plywood purchased wood veneer from wholesalers and makers mainly in Osaka and Tokyo (21 of them in Osaka, 17 in Tokyo, 5 in Shizuoka, 6 in Aichi and 2 in Fukuoka) and distributed it to 36 furniture producing areas around the country. ${ }^{46}$

The division of labor between furniture manufacturers and veneered plywood companies can also be found regarding the processing of wood veneer. It is said in the Fuchū producing area that "it was a conventional custom to entrust the veneer-gluing to wood veneer companies, so that

44. Based on an interview with Hironari Karakawa, Shachō [CEO] of the Karakawa Mokuzai [Karakawa Woodwork Co. Ltd.], conducted on Feb. 3, 2009. "Fuchū Kaguden [The History of the Fuchū Furniture]," Fuchū Kagushinbun [the Fuchū Furniture Newspaper], May 10, 1971. Ippei Mikami, "Fuchūtansu [The Fuchū Cabinet]," Fuchū Kagukōgyō Kyōdōkumiai [the Fuchū Furniture Industry Association], Fuchū no Kagu [The Fuchū Furniture] (1967): 10.

45. Based on interviews with Tetsuya Sadashige, President of the Sadashige Special Plywood, conducted on Dec. 29, 2008 and Feb. 3, 2009. Fuchū Kagukōgyō Kyōdōkumiai [the Fuchū Furniture Industry Association], Hiyaku [The Leap] (1975): 138.

46. Based on an interview with Tetsuya Sadashige, President of the Sadashige Special Plywood, conducted on Feb. 3, 2009. Regarding the companies from which the Sadashige Special Plywood purchased wood veneer, see Nihon Mokuseihin Gijutsukyōkai [the Japan Woodworking Technology Association], Tsukiita Handobukku [A Handbook for Wood Veneer] (Zenkoku Tsukiita Rengōkai [the National Wood Veneer Association], 1967): 74-77. 
wood veneer bought by a furniture company remained in the warehouse of the wood veneer company until it was brought out for gluing." ${ }^{47}$ Many wood veneer companies conducted both the purchase of material wood veneer and the making of veneered plywood. In fact, the production process at the Karakawa Lumber consisted of "first, the checking of material wood veneer, then the cutting, gluing, thermocompressing, polishing, mending and finishing processes and, finally the inspection of the product." ${ }^{28}$ The production process was the same at the Sadashige Special Plywood, and the company used sub-contractors when there were too many orders. ${ }^{49}$ This division of labor as to the making of veneered plywood can be thought to have derived from the high level of technical quality required. "Veneered plywood for furniture" included a wide variety of products. The qualities and the gluing methods of veneered plywood were different, depending on which part of the furniture it was used for." In particular, plywood used for the front side, which was called the "face of the furniture," had to be "the high-grade one in terms of both its quality and the gluing method." the division of labor. There were two gluing methods: namely, the dry method and the wet method. The dry method proceeded as follows: "Put an adhesive on the surface of the plywood and dry it for a moment, and then glue dried wood veneer to the plywood by pressing the former with an iron." On the other hand, the wet method proceeded as follows: "Put an adhesive on the surface of the plywood and, immediately, glue wet wood veneer to the plywood by hand." Until the early 1970s, the Karakawa Lumber had mostly depended on the dry method, although it required "high skills" and was considered "inefficient." Despite high material costs, the differentiation strategy to produce high-grade wood veneer furniture continued to be effective for furniture manufacturers in Fuchū. As a reason for this, it can be pointed out that the organic division of labor existed between furniture manufacturers and wood veneer companies, let alone that furniture manufacturers made the proper strategic choice

47. Fuchū Kagukōgyō Kyōdōkumiai, op. cit., 117.

48. "Kōjō Jikoshōkai: Karakawa Mokuzai Kōgyō Kabushikikaisha [Self-introduction of Factory: the Karakawa Woodwork Co. Ltd.]," Mokuzaikōgyō [The Woodworking Industry], Mar. 1976: 32.

49. Based on an interview with Tetsuya Sadashige, President of the Sadashige Special Plywood, conducted on Dec. 29, 2008.

50. “Kōjō Jikoshōkai: Karakawa Mokuzai Kōgyō Kabushikikaisha,” op. cit. 
corresponding to the demand structure of the furniture market.

\section{Conclusion}

During the postwar period of high economic growth, Fuchū, a newlyrisen furniture producing area, grew rapidly into one of the country's most prominent producing areas of high-grade wedding furniture. This was made possible by the unique production system established by leading medium-sized manufacturers, in which the quantity production method was combined with the production of high-grade goods. Attention should be paid to this system to produce high-grade goods in quantities, because previous researches have only stressed the aspect of mechanization and mass production. The following two points were crucial for the establishment of the production system specific to the Fuchū furniture producing area. Firstly, furniture manufacturers implemented the structural reform by establishing the planning department as an independent and specialized section and also by expanding and improving production facilities. By doing so, they sought to grow out of a "woodworking workshop dependent on craftsmen." Secondly, the sustained, organic division of labor existed between furniture manufacturers and furniturerelated businesses including veneered plywood companies. This division of labor in particular helped manufacturers construct the new production system in the following ways. Firstly, it realized and completed the productization of the wood veneer-based furniture design proposed by the planning department. Secondly, it urged manufacturers to expand and improve production facilities where, unlike the making of veneered plywood, the division of labor with sub-contractors was not established.

\section{Bibliography}

Chūshōkigyō Chōsakai [the Investigating Committee on Small and Medium-sized Enterprises]. Chūshōkōgyō ni Okeru Gijutsushinpo no Jittai [The Actual State of Technological Development concerning Small and Medium-sized Industrial Businesses]. Tokyo:Tōyōkeizai Shinpōsha, 1960.

Fuchū Kagukōgyō Kyōdōkumiai [the Fuchū Furniture Industry Association]. Fuchū no Kagu

[The Fuchū Furniture], 1967.

—. Hiyaku [The Leap], 1975.

Fuchū Shōkō Kaigisho [the Fuchū Chamber of Commerce and Industry]. Fuchū Shōkō Meikan [The Fuchū Business Directory], 1975.

—. Fuchū-shi Shōkōgyō Hattenshi [the Industrial History of Fuchū City], 1986. 
Hiroshima-ken [Hiroshima Prefecture]. Mokuseikagu Seizōgyō (Fuchū-shi) ni Kakawaru Sanchi Chüshōkigyō Shinkō Bijon [A Vision for the Development of Small and Mediumsized Businesses in the Producing Area: the Wood Furniture Industry in Fuchū City], 1980

Hiroshima-ken Chūshōkigyō Shidōsho [Hiroshima Prefectural Institute for Small and Medium-sized Businesses]. Hiroshima-ken Mokuseikagu Seizōgyō Sanchi Shindan Hōkokusho [The Report on the State of the Wood Furniture Producing Areas in Hiroshima Prefecture], 1968.

Hwang, Wanshung. Nihon no Jibasangyō: Sanchi Bunseki [Local Industries in Japan: the Analysis of Producing Areas].Tokyo:Zeimu Keiri Kyōkai [the Taxation Business and Accounting Association], 1997.

Itakura, Katsutaka and Yoshiyuki Kitamura. Jibasangyō no Chiiki [Areas of Local Industries]. Tokyo: Taimeidō, 1980

Itami, Hiroyuki, Shigeru Matsushima and Takeo kikkawa, eds. Sangyōshūseki no Honshitsu [The Essence of Industrial Cluster].Tokyo: Yuhikaku, 1998.

Kagumansurī [The Monthly Furniture Magazine], 1967-74.

Kagunenkan [The Furniture Yearbook].Tokyo: Keizaitsūshin, 1971.

Kagusangyō [The Furniture Industry], 1965-73.

Kitazawa, Yasuo. Kagu Interia Gyōkai [The Furniture and Interior Design Industry].Tokyo: Kyōikusha, 1979.

Kiyonari, Tadao. Gendai Chūshōkigyō no Shintenkai [The New Development of Today's Small and Medium-sized Businesses].Tokyo: Nihon Keizai Shinbunsha, 1972.

Kōgyō Tōkeihyō [Tables of Industrial Statistics].

Kōno, Yoshiyuki. "Mokkōkikai no Shinpo [The Development of Woodworking Machines]," Hiroshima-ken Kagukumiairengōkai [the Hiroshima Prefecture Furniture Makers' Association], Hiroshima-ken no Kagu: 20 Nen no Ayumi [The Furniture of Hiroshima Prefecture: 20 Years of Progress], 1978.

Kozono, Hiroshi. "Kaisō [Recollection]," Hiroshimakenritsu Kōgeishikenjō [Industrial Arts Inst. Hiroshima Prefecture] (ed), Sōritsu 30 Shūnen Kinenshi [The Memorial Magazine for the 30th Anniversary of Foundation], 1984.

Maeda, Yasumasa. "Fuchūkagu to Tomoni Ayumu [My Life with the Fuchū Furniture]," Fuchū Kagukōgyō Kyōdōkumiai [the Fuchū Furniture Industry Association], Fuchūkagu: 35 Nen no Ayumi [The Fuchū Furniture: 35 Years of Progress], 1985.

Mikami, Ippei. "Fuchūtansu [The Fuchū Cabinet]," Fuchū Kagukōgyō Kyōdōkumiai [the Fuchū Furniture Industry Association], Fuchū no Kagu [The Fuchū Furniture], 1967.

Mokkōkai [The Woodworking Industry], 1955-63.

Narita, Juichirō. Mokkōkikai Kōsakubinran [A Handbook for Woodworking with Machines]. Tokyo: Rikōgakusha, 1971.

Nihon Mokuseihin Gijutsukyōkai [the Japan Woodworking Technology Association]. Tsukiita Handobukku [A Handbook for Wood Veneer].Tokyo:Zenkoku Tsukiita Rengōkai [the National Wood Veneer Association], 1967.

Ōkawa, Kazushi. Kokuminshotoku [The National Income].Tokyo:Tōyōkeizai Shinpōsha, 1974.

Onizuka, Nobuyuki. "Hiroshimagyōkai no Hatten ni Matsuwaru Omoide [Memories about the Development of the Hiroshima Furniture Industry]," Hiroshima-ken Kagukumiairengōkai 
[the Hiroshima Prefecture Furniture Makers' Association], Hiroshima-ken no Kagu: 20 Nen no Ayumi [Furniture of Hiroshima Prefecture: 20 Years of Progress], 1978.

Sanyō Shinbun [the Sanyō Newspaper]

Sasaki, Kuichi. Gojūnen no Ayumi [50 years of Progress], Sasaki Mokkō Kabushikikaisha [the Sasaki Woodwork Co. Ltd.], 1979.

Seki,Mitsuhiro.Chiiki Chūshōkigyō no Kōzōchōsei [The Structural Adjustment of Local Small and Medium-sized Businesses], Tokyo:Shinhyōron, 1991.

Shōkō-shō Tōkeihyō [Tables of Statistics, Ministry of Commerce and Industry].

Sōmu-shō Tōkei-kyoku. [Statistic Bureau, Ministry of Internal Affairs and Communications], Shinban Nihon Chōkitōkei Sōran [The Comprehensive Long-term Statistics of Japan: the new edition].Tokyo: Nihon Tōkeikyōkai [the Japan Statistics Association], 2006.

Suzuki, Yoshitaka, Eisuke Daitō and Haruhito Takeda. Bijinesu no Rekishi [The History of Business].Tokyo: Yuhikaku, 2004.

Tsūshōsangyō-shō Seikatsusangyō-kyoku [Ministry of International Trade and Industry, Consumer Goods Industries Bureau]. Shōwa 50 Nendai no Seikatsuyōhinsangyō [The State of the Consumption Goods Industry between 1975 and 1984], 1976.

Ueda, Sōjirō and Takamasa Yokoyama. "Kagukogyō [The Furniture Industry]" Chūshōkigyō Chōsakai [the Investigating Committee on Small and Medium-sized Enterprises] ed. Chūshōkōgyō ni Okeru Gijutsushinpo no Jittai [The Actual State of Technological Development concerning Small and Medium-sized Industrial Businesses].Tokyo: Tōyōkeizai Shinpōsha, 1960.

Uranishi, Shōtarō. Omoidegusa, Hiroshima-ken no Kagu: 20 Nen no Ayumi [Memory,Furniture of Hiroshima Prefecture: 20 Years of Progress]. Hiroshima:Hiroshima-ken Kagukumiairengōkai [the Hiroshima Prefecture Furniture Makers' Association],1978.

Yamazaki, Mitsuru. Nihon no Jibasangyō [Local Industries in Japan].Tokyo: Daiyamondosha, 1977. 